\title{
Human Alveolar Macrophage
}

\section{Cytophilic Immunoglobulin G-mediated Phagocytosis of Protein A-Positive Staphylococci}

\author{
Henri A. Verbrugh, John R. Hoidal, Bach-Yen T. Nguyen, Jan Verhoef, \\ Paul G. Quie, and Phillip K. Peterson, Departments of Medicine and \\ Pediatrics, University of Minnesota School of Medicine, Minneapolis, \\ Minnesota 55455; Laboratory for Microbiology, University of Utrecht School \\ of Medicine, Utrecht 3511 GG, The Netherlands
}

A B S T R A C T Human alveolar macrophages (AM) have recently been reported to ingest and kill a strain of Staphylococcus aureus (502A) in the absence of opsonins. To further investigate the mechanism of nonopsonic recognition, we studied phagocytosis of 23 clinical and laboratory strains of S. aureus and Staphylococcus epidermidis by AM, and by blood polymorphonuclear leukocytes (PMN) and monocytes (MN). In the absence of opsonins, AM phagocytized 18 protein A-positive but not 5 protein A-negative strains of staphylococci, and the efficiency of phagocytosis directly correlated with the amount of protein A present in the bacterial cell wall $(r=0.86, P$ $<0.001$ ). Furthermore, AM rosetted around protein A-coated Sepharose beads, but not around beads without protein A. In contrast, PMN did not phagocytize nonopsonized staphylococci, and did not rosette around either type of Sepharose. MN phagocytized protein Apositive staphylococci, but much less efficiently than $\mathrm{AM}$, and showed some rosetting around protein Acoated Sepharose.

The nature of the AM receptor for protein A-positive staphylococci was studied. The surface of AM was positively stained with fluorescein-conjugated anti-

Portions of this work were presented at the Association of American Physicians, American Society for Clinical Investigation, and American Federation for Clinical Research National Meeting, San Francisco, Calif., 27 April 1981, and appeared in abstract form in 1981. Clin. Res. 29: 398a.

Dr. Hoidal is the recipient of a Young Investigator Award HL 24653-01 of the National Heart, Lung, and Blood Institute, Dr. Quie is the American Legion Heart Research Professor of Pediatrics. Address correspondence to Dr. Henri A. Verbrugh, Department of Medicine, University of Minnesota School of Medicine, Minneapolis, Minn. 55455.

Received for publication 20 April 1981 and in revised form 17 September 1981. body to human IgG, but not with IgA- or IgM-specific conjugates. No such surface-immunoglobulins were detected on PMN, and MN were only weakly positive for surface IgG. Pretreatment of AM with $F\left(a b^{\prime}\right)_{2}$ fragments specific for human IgG (anti-Fc) inhibited subsequent phagocytosis of protein A-positive staphylococci. There was no evidence that the AM surface IgG was aggregated or immunecomplexed.

From these studies we conclude that human AM possess cytophilic IgG antibodies, which can function as receptors for phagocytosis of protein A-positive staphylococci.

\section{INTRODUCTION}

As part of an endeavor to elucidate the mechanisms underlying the process of phagocytosis, our laboratories have studied the opsonic recognition of several bacterial species, including Staphylococcus aureus, by human peripheral blood phagocytes, i.e., the polymorphonuclear leukocytes $(\mathrm{PMN})^{1}$ and monocytes (MN) (1-3). Results of these studies and those of other investigators (4-6) have indicated that, although the requirement for opsonic factors may differ among strains of staphylococci, significant phagocytosis and killing of these bacteria will not occur in the complete absence of serum opsonins. Major staphylococcal opsonins are a fragment of the third component of complement (C3b) and IgG class of antibodies. The peptidoglycan component of the staphylococcal cell wall

${ }^{1}$ Abbreviations used in this paper: agg-IgG, heat-aggregated human IgG; AM, alveolar macrophages; FITC, fluorescein isothiocyanate; GHBSS, HBSS containing $0.1 \%$ gelatin; HBSS, Hanks' balanced salt solution; MN, monocytes; PBS, phosphate-buffered saline; PMN, polymorphonuclear leukocytes; SRBC, sheep erythrocytes. 
has been proposed to be the key bacterial structure that interacts with these opsonins $(7,8)$.

In an attempt to define the opsonic requirements for bacterial phagocytosis by extravascular phagocytes, we have recently studied the interactions between staphylococci and human alveolar macrophages (AM) (9, 10). These studies led to the surprising observation that AM were able to ingest and kill a strain of $S$. aureus (502A) in the absence of opsonins. The goal of the present investigation was to determine the basis of this phenomenon. A total of 23 selected staphylococcal strains with major differences in cell wall composition were studied. We have found that protein $A$ is the cell wall component of staphylococci that is recognized by $\mathrm{AM}$, and discovered that human AM possess cytophilic IgG antibodies. Nonopsonic phagocytosis appears to result from the binding of protein $\mathrm{A}$ to the $\mathrm{Fc}$ portion of the IgG molecules on the surface of AM.

\section{METHODS}

Bacterial strains and cultural conditions. Previously described laboratory strains of $S$. aureus were $502 \mathrm{~A}$, Ev, Cowan I, EMS (an induced protein A-deficient mutant of Cowan I provided by A. Forsgren, Mälmo University, Mälmo, Sweden), Wood 46 (a noninduced protein A-poor strain), H HSmR (a spontaneous streptomycin-resistant mutant of strain H), 52A5 (a teichoic acid-deficient mutant of HSmR, both provided by J. T. Park, Tufts University, Boston, Mass.), and the encapsulated $M$ and Smith strains with their respective nonencapsulated variant strains (Smith compact and M variant), kindly provided by A. Melly, Vanderbilt University, Nashville, Tenn. $(1,7,8,11)$. Another related pair of $S$. aureus strains, one of which was coagulase- and clumping factor-negative, was kindly donated by C. P. A. Van Boven (University of Limburg, Maastricht, the Netherlands). In addition, six strains of S. aureus and three strains of Staphylococcus epidermidis were fresh clinical isolates from the blood of bacteremic patients. Escherichia coli ON2 (serotype 022:H16) is a serum resistant strain provided by B. Björksten (University of Umeå, Umeå, Sweden) (12). All strains were maintained on blood agar plates at $4^{\circ} \mathrm{C}$.

For each experiment bacteria were grown in Mueller Hinton broth (Difco Laboratories, Detroit, Mich.) in a $37^{\circ} \mathrm{C}$ shaking incubator for $18 \mathrm{~h}$, washed three times with phosphate-buffered saline (PBS) pH 7.4, and resuspended in PBS to a concentration of $5 \times 10^{8}$ microorganisms $/ \mathrm{ml}$. For phagocytosis studies, the bacteria were radiolabeled by inoculating into $10 \mathrm{ml}$ Mueller Hinton broth containing $20 \mu \mathrm{Ci}$ of $[2,8-$ ${ }^{3} \mathrm{H}$ ]adenine (sp act $34 \mathrm{Ci} / \mathrm{mM}$, ICN Corporation, Irving, Calif.), as previously described (7).

Isolation of phagocytic cells. PMN and MN were recovered from venous donor blood drawn into heparinized syringes (10 $\mathrm{U}$ heparin $/ \mathrm{ml}$ blood) using a method modified from Böyum (13) as described previously (7). The final PMN pellets were resuspended to a concentration of $5 \times 10^{6} \mathrm{PMN} /$ $\mathrm{ml}$ in Hanks' balanced salt solution (HBSS) containing $0.1 \%$ gelatin (GHBSS). Purity was evaluated by Wright's stained smears and viability by trypan blue exclusion; both exceeded $95 \%$.

The MN containing mononuclear cell layer was washed three times with GHBSS, and total and differential counts were performed. The percentage of $\mathrm{MN}$ in these prepara- tions varied between 25 and $45 \%$ with the remainder of the cell population being primarily lymphocytes. The suspensions were adjusted to contain $5 \times 10^{6} \mathrm{MN} / \mathrm{ml}$ in GHBSS. MN viability was always $>95 \%$. In some experiments $M N$ were further purified using a slight modification of the method of Ackerman and Douglas $(9,14)$ using microexudate-coated surfaces. MN purity in these suspensions was always $>95 \%$ and viability was $\geq 90 \%$.

AM were obtained from normal donors by subsegmental saline lavage of the lingula of the left lung, or the middle lobe of the right lung, as previously described (15). AM were obtained from smokers and nonsmokers. AM in the recovered lavage fluid were washed three times with GHBSS and resuspended at a concentration of $5 \times 10^{6} \mathrm{AM} / \mathrm{ml}$ GHBSS. Purity of AM suspensions was $\geq 85 \%$ (remaining cells were primarily lymphocytes) and viability exceeded $94 \%$ in all cases. The cell-free lavage fluids were routinely concentrated 150 -fold by positive pressure ultrafiltration through a PM 10 membrane (Amicon Corp., Scientific Sys. Div., Lexington, Mass.) and stored at $-70^{\circ} \mathrm{C}$ until use.

To study tissue macrophages from another site of the human body, about 2.5 liters of peritoneal dialysate was obtained from four clinically stable patients on chronic peritoneal dialysis for renal failure. None of the patients had a history of previous peritonitis. Peritoneal cells were prepared in a manner similar to that for AM. Between 20 and 70 $\times 10^{6}$ cells were obtained and the final suspensions (in GHBSS) contained a mean (range) percent of $70(64-83) \%$ of macrophages, 24 (14-30)\% lymphocytes, and 6 (3-10)\% PMN. Viability exceeded $95 \%$ in each case.

For some experiments AM were also obtained from 2-2.5kg wild rabbits, 275-325-g Sprague-Dawley rats, and from 100-g Syrian golden hamsters by a standard lung lavage technique using sterile saline (16). Each of the suspensions contained $\geq 95 \% A M$, and AM viability was $\geq 90 \%$.

Opsonins and opsonization procedure. Serum from 10 healthy donors was pooled and stored in $1-\mathrm{ml}$ portions at $-70^{\circ} \mathrm{C}$. Just before use, serum was thawed and diluted to $10 \%$ in GHBSS. $100 \mu$ l of the bacterial suspension $\left(\sim 5 \times 10^{7}\right.$ microorganisms) was mixed with $0.9 \mathrm{ml}$ of $10 \%$ serum or with $0.9 \mathrm{ml} \mathrm{GHBSS}$, and incubated for $30 \mathrm{~min}$ at $37^{\circ} \mathrm{C}$. The suspension was then designated opsonized (10\% serum) or nonopsonized (GHBSS) bacteria, and held at $4^{\circ} \mathrm{C}$ until use. Heat-aggregated human IgG (agg-IgG, $10 \mathrm{mg} / \mathrm{ml}$ ) was a gift of Dr. F. G. Cosio (Department of Pediatrics, University of Minnesota School of Medicine, Minneapolis).

Phagocytosis assay. The uptake of opsonized and nonopsonized bacteria by phagocytes was determined using radiolabeled bacteria in an assay that has been described in detail previously $(2,8)$. Briefly, $100 \mu \mathrm{l}$ of the opsonized or nonopsonized bacterial suspension was mixed with $100 \mu \mathrm{l}$ of either PMN, MN, or AM in polypropylene vials (Bio-vials, Beckman Instruments Inc., Fullerton, Calif.), and phagocytosis was allowed to proceed for indicated times in a $37^{\circ} \mathrm{C}$ shaking incubator. The final bacteria to phagocyte ratio was $\sim$ 10:1. Phagocytosis was interrupted by adding $3-\mathrm{ml}$ icecold PBS to the mixture. Nonphagocyte-associated bacteria were removed by three cycles of differential centrifugation $\left(5 \mathrm{~min}, 160 \mathrm{~g}, 4^{\circ} \mathrm{C}\right.$ ) and the phagocyte-associated radioactivity in the final pellets was determined by liquid scintillation counting as described (9). Phagocytosis was expressed as a percent uptake of total added radioactivity, determined in a separate vial (2).

Measurement of superoxide anion $\left(\mathrm{O}_{2}^{-}\right)$production. Release of $\mathrm{O}_{2}^{-}$by $\mathrm{AM}$ was measured by the cytochrome $c$ reduction method (17). $1 \mathrm{ml}$ reaction mixtures containing 5 $\times 10^{6} \mathrm{AM}$ with or without bacteria $\left(2.5 \times 10^{8}\right)$ were incu- 
bated with shaking for $20 \mathrm{~min}$ at $37^{\circ} \mathrm{C}$ in the presence of horse heart ferricytochrome $c$ (Sigma Chemical Co., St. Louis, Mo.). Parallel identical mixtures were incubated containing in addition $50 \mu \mathrm{g} / \mathrm{ml}$ superoxide dismutase $(2,000$ $\mathrm{U} / \mathrm{ml}$, Truett Laboratories, Dallas, Tex.). Identical samples with and without superoxide dismutase were also run at $4^{\circ} \mathrm{C}$. After incubation, the reaction mixtures were held in an icebath, and centrifuged $\left(10 \mathrm{~min}, 800 \mathrm{~g}, 4^{\circ} \mathrm{C}\right)$. The absorbance at $550 \mathrm{~nm}$ of each supernatant was measured in a Beckman 24 spectrophotometer (Beckman Instruments, Inc.) using the $4^{\circ} \mathrm{C}$ incubation mixtures as blanks. Results are expressed as nanomoles of superoxide dismutase inhibitable cytochrome $c$ reduced per $20 \mathrm{~min} / 5 \times 10^{6} \mathrm{AM}$ (17).

Measurement of hexose monophosphate shunt activity. The hexose monophosphate shunt activity of AM was assessed by the conversion of $\left[1-{ }^{14} \mathrm{C}\right]$ glucose to ${ }^{14} \mathrm{CO}_{2}$, as previously described (17). Incubation mixtures contained 5 $\times 10^{6} \mathrm{AM}$, bacteria $\left(2.5 \times 10^{8}\right), 1.0 \mu \mathrm{M}$ glucose, and $1.0 \mu \mathrm{Ci}$ as $\left[1-{ }^{14} \mathrm{C}\right]$ glucose (New England Nuclear, Boston, Mass.). ${ }^{14} \mathrm{CO}_{2}$ produced during a 20 -min incubation in a $37^{\circ} \mathrm{C}$ shaking water-bath was trapped on filter paper saturated with $20 \%$ sodium hydroxide. Filter papers were allowed to dry at room temperature, and radioactivity in the filter papers was determined by liquid scintillation counting. Results are expressed as counts per minute per $20 \mathrm{~min} / 5 \times 10^{6} \mathrm{AM}(16)$. Parallel tubes contained AM without bacteria ("resting" AM), bacteria without AM, and GHBSS alone.

Quantitation of staphylococcal protein A. The amount of protein A present on the surface of intact staphylococci was measured using the ability of protein $A$ to agglutinate antibody-coated erythrocytes (18). A $1 \%$ suspension of sheep erythrocytes (SRBC) was sensitized with a subagglutinating dose of rabbit IgG antibody to SRBC (N. L. Cappel Laboratories, Inc., Cochranville, $\mathrm{Pa}$.), washed, and $0.1 \mathrm{ml}$ was aliquoted into $\mathrm{V}$-shaped wells of Cooke microtiter trays (Dynatech Laboratories, Inc., Alexandria, Va.). $100 \mu \mathrm{l}$ of serial twofold dilutions of the bacterial suspension $\left(1 \times 10^{9}\right.$ microorganisms $/ \mathrm{ml}$ ) were added to the wells, thoroughly mixed with the sensitized SRBC, and incubated for $4 \mathrm{~h}$ at $37^{\circ} \mathrm{C}$. The hemagglutinating titer of each strain was read as the highest dilution of the bacterial suspension that gave visible agglutination. Bacterial hemagglutinating titers were compared to the hemagglutinating titer of a simultaneously run solution containing $5 \mu \mathrm{g} / \mathrm{ml}$ of purified protein A (Pharmacia Fine Chemicals, Div. of Pharmacia Inc., Piscataway, N. J.). This allowed for the amount of protein of each strain to be expressed as picograms of protein $\mathrm{A} / 1 \times 10^{6}$ cocci. The results are based on duplicate tests performed on 3 separate $\mathrm{d}$; day-to-day variation in hemagglutinating titers never exceeded one twofold dilution step. Appropriate controls were bacteria incubated with nonsensitized SRBC, and sensitized SRBC incubated with PBS alone. The suspensions were in PBS.

"Sepharose-rosette" assay. The ability of PMN, MN, and AM to form rosettes around beads of Sepharose ${ }^{\circledR}$ CL-4B with covalently linked protein A residues (Pharmacia Fine Chemicals) was determined by incubating $0.5 \mathrm{ml}$ of the phagocyte suspension with $0.1 \mathrm{ml}$ beads (packed volume) for $30 \mathrm{~min}$ at $37^{\circ} \mathrm{C}$ with intermittent agitation. The preswollen Sepharose was allowed to equilibrate with GHBSS before use. After incubation, an equal volume of methylene blue $(0.1 \%)$ was added and samples were sealed under cover slips on clean microscope slides. Rosetting of phagocytic cells around Sepharose beads was evaluated on a Zeiss photomicroscope (Carl Zeiss, Inc., Oberkocten, West Germany), and the percentage of beads that had three or more phagocytes attached was determined by screening 200 beads. Rosetting of phago- cytes around Sepharose CL-4B without covalently linked protein A was likewise studied.

Surface immunoglobulin assay. Immunofluorescent staining of PMN, MN, and AM for the presence of surface immunoglobulins was performed with the kind assistance of K. J. Gajl-Peczalska (Cell-Marker Laboratory, University of Minnesota School of Medicine, Minneapolis) according to previously described methods (19). Briefly, $1 \times 10^{6}$ cells in PBS containing $2 \%$ fetal calf serum and $15 \mathrm{mg} / 100 \mathrm{ml}$ sodium azide were mixed with 2 vol of fluorescein isothiocyanate-conjugated (FITC) antibodies, polyvalent or monospecific for the major heavy-chain classes $(\alpha, \gamma, \mu)$. FITCprotein A (Pharmacia Fine Chemicals), diluted 1:20, was also used. The cells were incubated at $4^{\circ} \mathrm{C}$ for $45 \mathrm{~min}$ and then washed three times with the same PBS by centrifugation (5 min at 1,200 rpm). After decanting, the final pellets were gently resuspended in the fluid remaining in the tubes, and samples were sealed under cover slips on clean microscope slides. Slides were examined on a Zeiss universal photomicroscope equipped with epifluorescence, phase contrast, and photography systems.

Trypsinization of staphylococci. To remove cell surface proteins, staphylococci $\left(5 \times 10^{8} \mathrm{ml}\right.$ in HBSS $)$ were incubated with $1 \mathrm{mg} / \mathrm{ml}$ HBSS of trypsin (type IX, Sigma Chemical Co.) for $30 \mathrm{~min}$ at $37^{\circ} \mathrm{C}$. After incubation, trypsin activity was neutralized by adding a twofold excess of chicken egg white trypsin inhibitor (type III-0, Sigma Chemical Co.), and washing the bacteria three times with PBS. The final bacterial pellet was resuspended with GHBSS to $5 \times 10^{8}$ bacteria/ml. Control bacteria were incubated with HBSS alone and treated likewise.

Pretreatment of AM. In some experiments AM $\left(5 \times 10^{6} /\right.$ $\mathrm{ml}$ in HBSS) were incubated for indicated times at $37^{\circ} \mathrm{C}$ with one of the following substances: trypsin (type IX, Sigma Chemical Co.), pronase (type VI, Sigma Chemical Co.); neuraminidase (type VIII, Sigma Chemical Co.), purified protein A (Pharmacia Fine Chemicals), or goat $F\left(\mathbf{a b}^{\prime}\right)_{2}$ fragments specific for the Fc portion of human IgG (heavy chain specific) (N. L. Cappell Laboratories Inc., Lot 14075). AM were likewise treated with $1 \mathrm{mg} / \mathrm{ml}$ papain (type III, Sigma Chemical Co.) in the presence of $0.01 \mathrm{M}$ cystein and $2 \mathrm{mM}$ EDTA. After incubation, AM were washed twice with cold GHBSS, resuspended to the original concentration, and immediately used. Excess trypsin inhibitor (type III-0, Sigma Chemical Co.) or bovine serum albumin (Reheis Co., Inc., Phoenix, Ariz.) were added after incubation of AM with trypsin and pronase, respectively. Control AM were incubated with HBSS alone and likewise treated.

Pretreatment of PMN. For some studies PMN $\left(5 \times 10^{6} /\right.$ $\mathrm{ml})$ were incubated with $1 \mathrm{mg}$ agg- $\mathrm{IgG} / \mathrm{ml}$ or with concentrated lung lavage fluid for $2.5 \mathrm{~h}$ at $4^{\circ} \mathrm{C}$. After incubation these cells were washed twice with cold GHBSS and used immediately.

Statistical analysis. Standard error was used as an estimate of variance and statistical significance was assessed using the Student's $t$ test for paired observations. The Pearson product-moment correlation coefficient $(r)$ was used to measure linear correlations between two variables $(20)$.

\section{RESULTS}

Phagocytosis of clinical isolates of S. aureus. To extend our previous observation on the nonopsonic uptake of a laboratory strain of S. aureus by AM (9), initial experiments in this study were performed with freshly isolated clinical strains. The kinetics of phago- 
cytosis of four such $S$. aureus strains by PMN, MN, and $A M$ is given in Fig. 1. Phagocytosis was determined after 5-, 15-, and 60-min incubation, and opsonized as well as nonopsonized staphylococci were used. Opsonized bacteria were recognized and readily taken up by all three types of phagocytic cells with $40-60 \%$ of the staphylococci being phagocytized after 5-min incubation.

The capacity of AM to phagocytize $S$. aureus in the absence of opsonins was confirmed with three of the four clinical isolates. Although the rate of uptake of these three nonopsonized bacteria was slower than that of opsonized bacteria, 75-80\% were AM-associated after 60-min incubation. One strain was not well recognized by AM in the absence of opsonins ( $30 \%$ uptake after $60 \mathrm{~min}$, Fig. 1). In contrast to $\mathrm{AM}, \mathrm{PMN}$, and MN phagocytosis of nonopsonized $S$. aureus was $<5$ and $20 \%$, respectively (Fig. 1). MN were somewhat better than PMN in recognizing nonopsonized staphylococci, and, interestingly, MN showed the poorest uptake of the one strain that was also relatively poorly taken up by AM (Fig. 1). Nonopsonized E. coli ON2 was not phagocytized by PMN, MN, and AM (uptake $\leq 3 \%$, data not shown). Unless specifically stated, further data is presented for nonopsonized staphylococci only.

Phagocytosis of laboratory strains of S. aureus and clinical isolates of S. epidermidis. To determine the recognition site for AM in the cell wall of staphylo- cocci, we next studied the phagocytosis of 10 strains with known differences in cell wall composition. Strains included S. aureus 502A, Cowan I (a protein A "rich" strain), EMS, and Wood 46 (both protein A "poor"), a related pair of strains, one of which was coagulase- and clumping factor-negative, another pair of strains (HSmR and 52A5) one of which was deficient in cell wall teichoic acid (52A5), and two clinical isolates of S. epidermidis (protein A "negative").

After 60-min incubation the mean (range) percent phagocytosis of the 10 strains was $6(1-20) \%$ by PMN, $13(3-29) \%$ by $\mathrm{MN}$, and 46 (8-87)\% by AM (Fig. 2). AM uptake of staphylococci was good (72-87\%) with four strains, intermediate (31-48\%) with two strains, and poor (8-13\%) with the remaining four strains. AM from smokers and nonsmokers gave very similar results as did AM from male and female donors (data not shown). The strains that were well phagocytized by AM were $502 \mathrm{~A}$, Cowan I, and the coagulase-positive and -negative pair of $S$. aureus strains. Poor uptake was observed with both strains of $S$. epidermidis, and with protein A-deficient $S$. aureus Wood 46 and EMS strains. The teichoic acid-deficient $52 \mathrm{~A} 5$ strain and its parent strain HSmR showed intermediate phagocytosis by AM. Collectively, the data suggested that AM recognition of nonopsonized staphylococci may depend on the presence of cell wall protein $A$, and that teichoic acid, clumping factor, and coagulase production were not greatly involved.

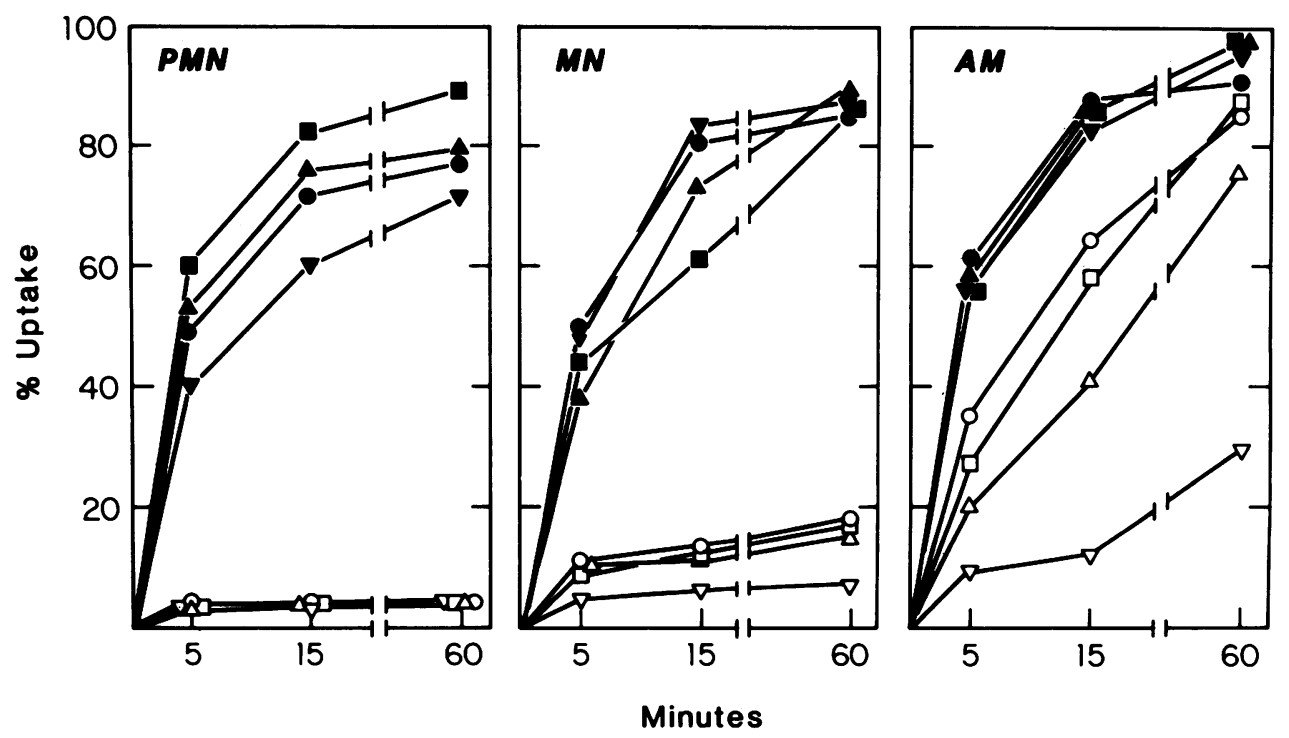

FIgURE 1 Phagocytosis of four fresh clinical isolates of S. aureus by PMN, MN, and AM. The percent uptake of opsonized (closed symbols) and nonopsonized (open symbols) bacteria by phagocytic cells was determined after 5,15 , and $60 \mathrm{~min}$ of incubation. The bacteria to phagocyte ratio was 10:1. Opsonized and nonopsonized staphylococci were obtained by incubation (30 min at $37^{\circ} \mathrm{C}$ ) in $10 \%$ normal pooled human serum and GHBSS, respectively, before adding to the phagocytes. 
Although MN uptake of staphylococci was much less efficient (Figs. 1 and 2), the rank order of uptake of the strains closely paralleled the order of phagocytosis found with AM. Thus, strains that were well recognized by $A M$ were also phagocytized to some extent by $\mathrm{MN}$, and strains not well recognized by $\mathrm{AM}$ were likewise poorly taken up by $\mathrm{MN}$. When the data for uptake of laboratory and clinical strains $(n=14)$ were subjected to linear regression analysis, the uptake by $\mathrm{AM}$ and $\mathrm{MN}$ correlated very well. (slope $b=3.6$, correlation coefficient $r=0.86, P<0.001$ ).

Role of protein A in phagocytosis of staphylococci. To further define the potential role of protein A, the amount of protein A available on the surface of a total of 22 strains of staphylococci was determined. Five strains (three S. epidermidis, S. aureus $\mathrm{M}$, and EMS) had undetectable cell surface protein A $\left(<10 \mathrm{pg} / 10^{6}\right.$ cocci). Protein A content of the remaining strains (all $S$. aureus) varied from $140-6,000 \mathrm{pg} / 10^{6}$ cocci. AM phagocytosis was $\leq 6 \%$ for the five protein A-negative strains, and was found to directly correlate with the amount of surface protein A for the 17 protein A-positive S. aureus strains (Fig. 3). Trypsinization of four protein A-rich strains (protein A content $\geq 5,000 \mathrm{pg} /$ $10^{6}$ cocci) removed $80-90 \%$ of their surface protein $A$, and their uptake by $\mathrm{AM}$ decreased accordingly from $\geq 75 \%$ to $\leq 24 \%$ (data not presented in Fig. 3).

$A M$ rosetting around Sepharose. Because the above results argued for protein $A$ as the recognition site for $\mathrm{AM}$, we next tested the hypothesis that $\mathrm{AM}$ would recognize other protein A-bearing surfaces.

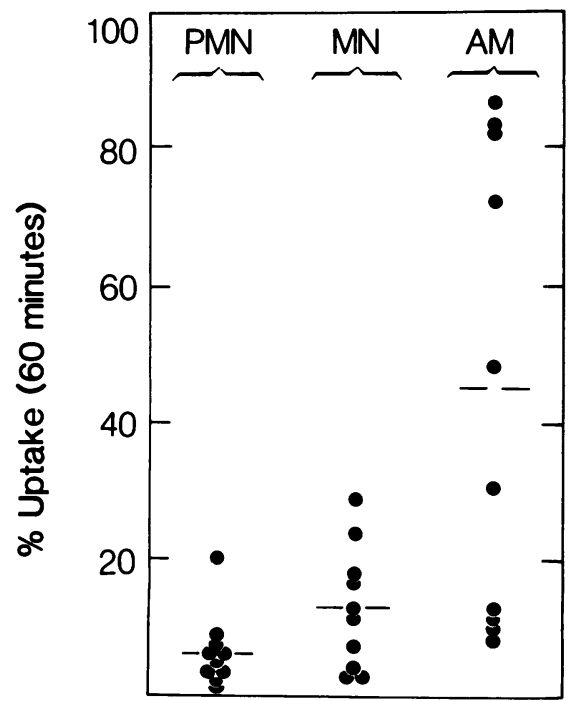

FIgURE 2 Phagocytosis of nonopsonized laboratory strains of $S$. aureus $(n=8)$ and fresh clinical isolates of $S$. epidermidis $(n=2)$ by PMN, MN, and AM. The percent uptake of bacteria by phagocytic cells was determined after 60-min incubation. The bacteria to phagocyte ratio was 10:1.

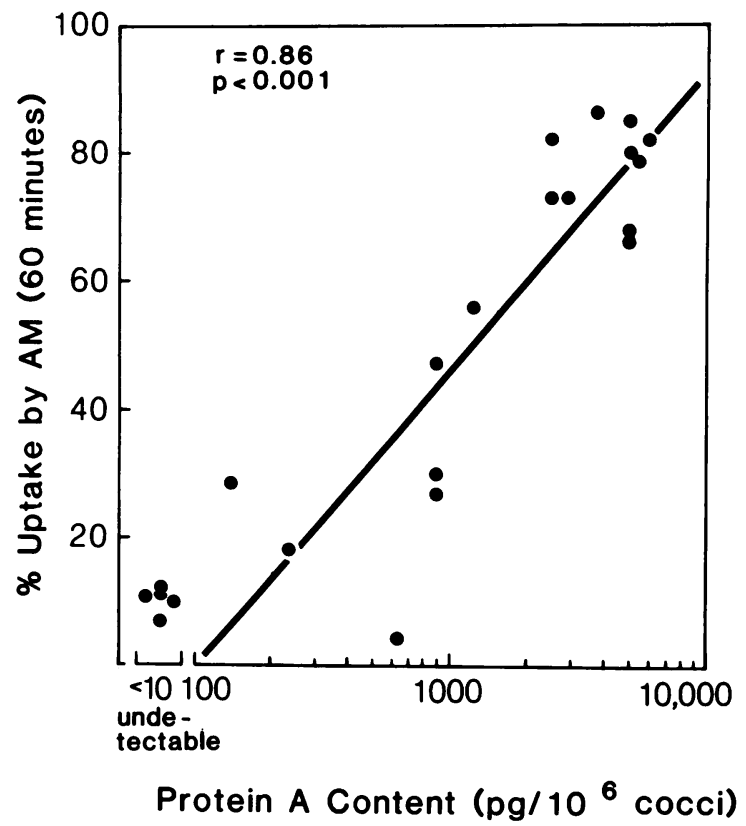

Figure 3 Correlation between cell wall protein A content of 22 strains of staphylococci and their nonopsonic phagocytosis by AM. The protein A content of the strains was determined by passive hemagglutination of sensitized SRBC. Phagocytosis was determined as in the legend of Fig. 2. $r$, correlation coefficient.

Therefore, the ability of PMN, MN, and AM to rosette around protein A-coated beads by Sepharose CL-4B was evaluated.

AM avidly rosetted around protein A-coated Sepharose, but not around Sepharose without protein A (Fig. 4). Rosetting of MN around protein A-Sepharose occurred much less frequently, and was virtually absent with PMN (Fig. 4) and neither cell rosetted around Sepharose without protein A (not shown in Fig. 4): The percentage of protein A-coated beads that had three or more phagocytes attached was $\leq 6 \%$ for PMN, 25-35\% for $\mathrm{MN}$, and $\geq 90 \%$ for $\mathrm{AM}$. In addition, beads positive for AM rosettes regularly had $>10 \mathrm{AM}$ attached and AM-induced "bridging", i.e., agglutination, of beads occurred (Fig. 4). Such bridging was never observed with $\mathrm{MN}$ or PMN, and rosette-positive beads always had fewer than six cells attached to them.

Metabolic responses of AM. The uptake of nonopsonized staphylococci by AM was accompanied by an increase in the rate of conversion of $\left[1-{ }^{14} \mathrm{C}\right]$ glucose to ${ }^{14} \mathrm{CO}_{2}$ and in the release of $\mathrm{O}_{2}^{-}$by $\mathrm{AM}$ (Table $\mathrm{I}$ ). Incubation of $\mathrm{AM}$ with a strain rich in protein $\mathrm{A}$ (Cowan I, 5,000 pg protein $A / 10^{6}$ cocci) induced a fourfold rise in glucose oxidation and a twofold rise in the amount of $\mathrm{O}_{2}^{-}$released. In contrast, the protein A-negative mutant strain EMS did not induce an increase in superoxide release, and only a twofold rise 


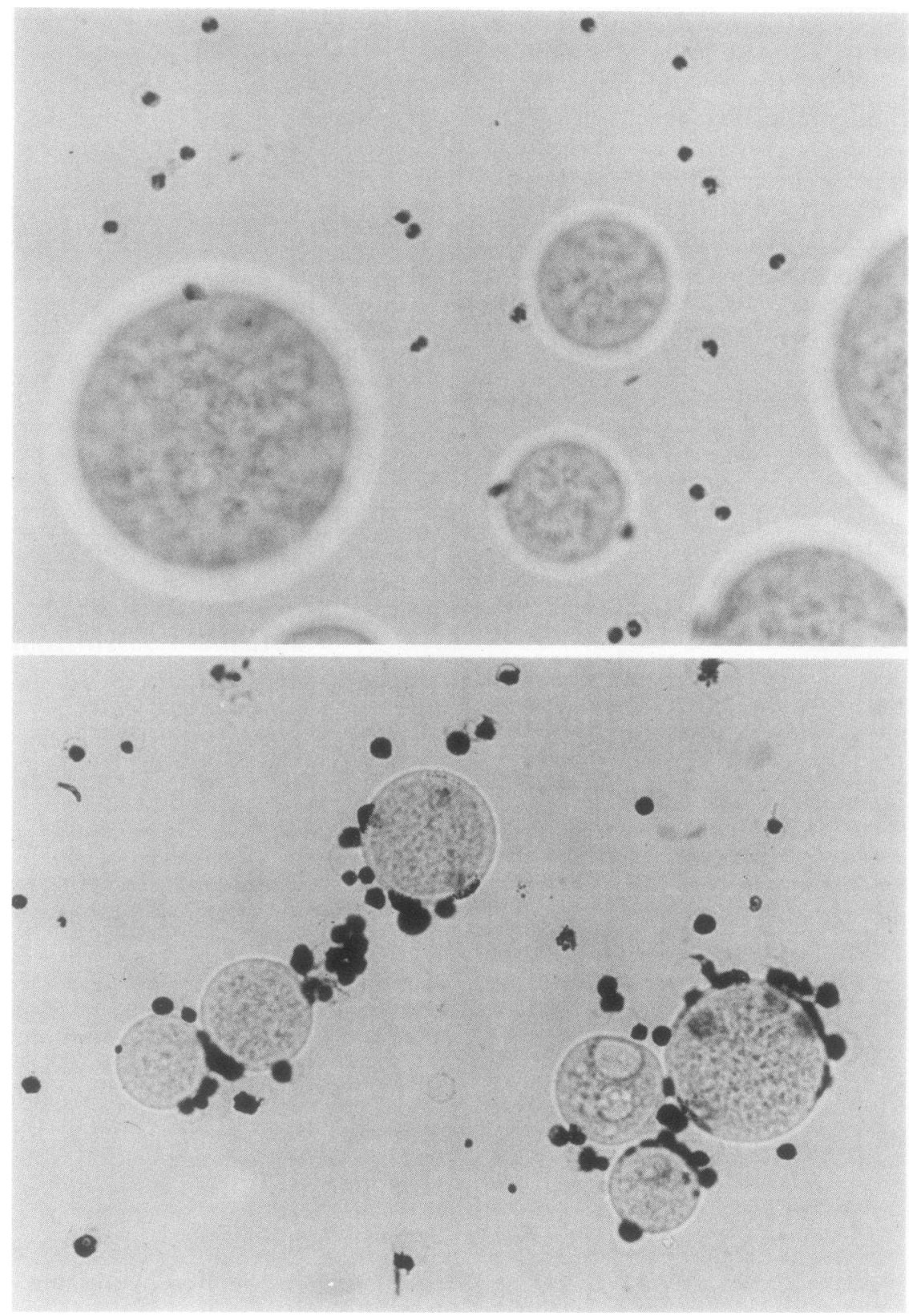

Figure 4 Rosetting of PMN (upper plate) and AM (lower plate) around Sepharose CL-4B with covalently linked protein A. Note positive rosettes with AM, but no rosetting of PMN. $\times 125-160$.

in the rate of glucose oxidation was observed (Table I). No significant differences were observed when live and heat-killed $\left(30 \mathrm{~min}, 70^{\circ} \mathrm{C}\right)$ bacteria were compared (datá not shown).

Detection of surface immunoglobulins on $A M$. Since these experiments indicated that protein $A$ was the bacterial ligand for AM phagocytosis of nonopson- ized staphylococci, and protein $A$ is known to bind nonspecifically to immunoglobulins (21), purified preparations of PMN, MN, and AM were studied for the presence of surface-immunoglobulins by immunofluorescence microscopy.

AM showed relatively intense fluorescence when stained with polyvalent or $\gamma$-chain specific antisera 
TABLE I

Metabolic Responses of AM to Challenge with Nonopsonized S. aureus

\begin{tabular}{lcc} 
& \multicolumn{2}{c}{ AM metabolic activity } \\
\cline { 2 - 3 } \multicolumn{1}{c}{ AM challenge } & $\begin{array}{c}\text { Hexose monophosphate } \\
\text { shunt }\end{array}$ & $\mathrm{O}_{\mathbf{2}}^{-}$production \\
\hline & $c p m / 20 \mathrm{~min} / 5 \times 10^{\circ}$ cells & $n M / 20 \mathrm{~min} / 5 \times 10^{\circ}$ cells \\
None ("resting" AM) & $1,811 \pm 147 \S$ & $7.1 \pm 0.1$ \\
S. aureus EMS & $3,931 \pm 318$ & $6.3 \pm 0.2$ \\
S. aureus Cowan I & $9,475 \pm 372$ & $14.1 \pm 0.8$ \\
\hline
\end{tabular}

- $\mathrm{AM}$ were incubated $\left(20 \mathrm{~min}\right.$ at $\left.37^{\circ} \mathrm{C}\right)$ with strain $\mathrm{EMS}$ (protein A-negative) or strain Cowan I (protein A-positive) at a final bacteria to macrophage ratio of 50:1.

$\$$ Hexose monophosphate shunt activity was assessed by the release of ${ }^{14} \mathrm{CO}_{2}$ from [1-

${ }^{14} \mathrm{C}$ ] glucose, and $\mathrm{O}_{2}^{-}$production by the reduction of extracellular ferricytochrome $c$; see Methods.

\& Results are expressed as means $\pm \mathrm{SE}$ of four separate experiments.

and with FITC-protein A, but were negative with $\alpha$ or $\mu$-chain specific conjugates (Fig. 5). AM from smokers and nonsmokers were found to have surface IgG. In addition to surface IgG, smoker AM also contained variable amounts of yellow autofluorescent material that seemed to be localized within cytoplasmic granules or vacuoles. Smoker AM autofluorescence has been reported before (22). MN were weakly positive for surface IgG, and PMN did not show any fluorescence with the antisera used (data not shown). These findings demonstrate that, in contrast to blood PMN and MN, AM carry appreciable amounts of membrane-bound IgG that may be involved in protein A-mediated uptake of staphylococci.

Inhibition of AM phagocytosis. Treatment of AM with trypsin or pronase for $30 \mathrm{~min}$ had little effect on the ability of AM to phagocytize nonopsonized S. aureus Cowan I, but greatly inhibited the uptake of opsonized bacteria (Table II). Neuraminidase (30 min) had little or no effect on the uptake of either opsonized

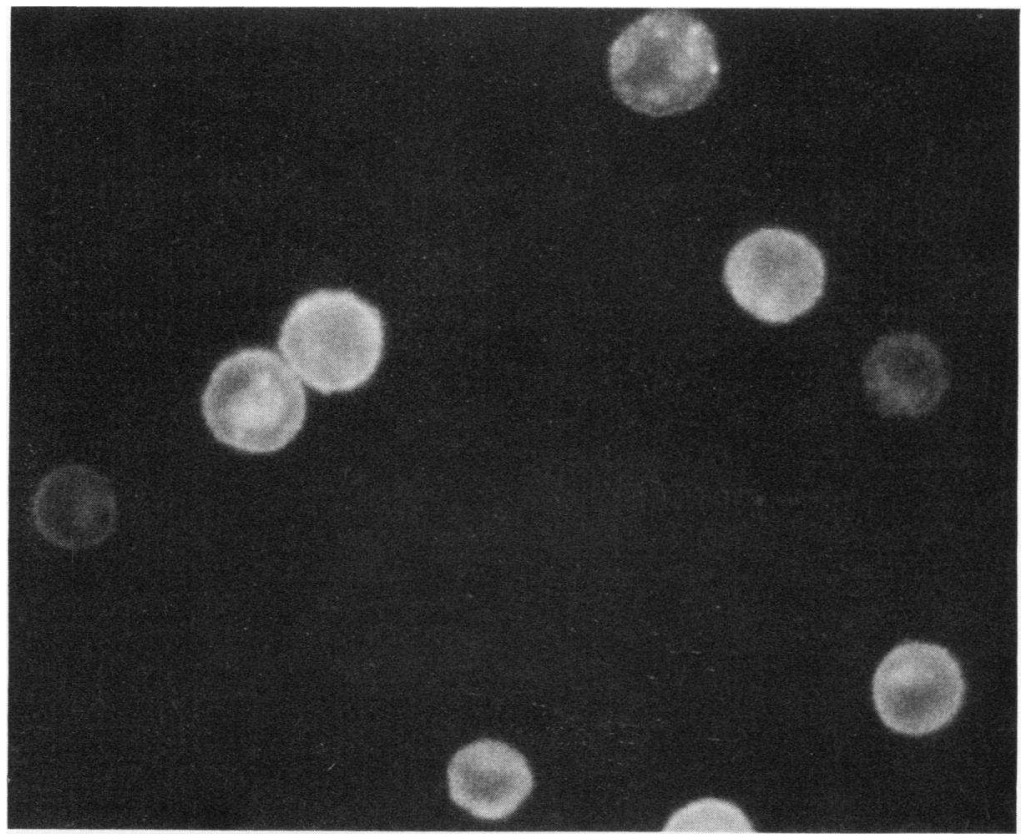

Figure 5 Plasma membrane-associated IgG on AM of a nonsmoker. Note uniform surface fluorescence and size of nonsmoker AM. 
or nonopsonized staphylococci. It was additionally found that treatment of AM with trypsin, pronase, or papain for $30 \mathrm{~min}$ did not result in extensive loss of AM surface IgG; focal loss of the dense fluorescent "coat" of some AM was noted, resulting in a "stippled" appearance of these cells (data not shown). However, when incubation of AM with each of these three enzymes was extended to $2 \mathrm{~h}$, virtually all surface IgG was removed.

Opsonization of protein A-rich strains with $10 \%$ normal serum greatly reduced their ability to agglutinate sensitized SRBC. The agglutination titers of four protein A-rich strains, including $S$. aureus Cowan I, were decreased by $84-97 \%$ after opsonization in $10 \%$ serum. Taken together, these findings indicate that opsonization of $S$. aureus masks cell surface protein A residues, and that these bacteria are taken up by $\mathrm{AM}$ via a trypsin- and pronase-sensitive receptor mechanism. The uptake of nonopsonized S. aureus, however, depends on protein $A$ and is mediated through trypsinand pronase-insensitive receptors of $\mathrm{AM}$, and may involve surface IgG.

To further define the role of surface IgG in phagocytosis, AM were pretreated with soluble purified protein $A$ or with $F\left(a b^{\prime}\right)_{2}$ fragments specific for the $F c$ part of IgG (anti-Fc). The uptake of opsonized S. aureus Cowan I was little affected by protein $\mathrm{A}$ or antiFc treatment of AM, but the uptake of nonopsonized staphylococci was inhibited (Table III). This observation lends further support to the hypothesis that opsonized and nonopsonized $S$. aureus are phagocytized via distinct $A M$ receptor mechanisms, and that the receptor for nonopsonized staphylococci is AM surface IgG.
Nature of AM surface IgG. The AM surface IgG was of a different nature than the IgG found on the surface of PMN pretreated with agg-IgG. The aggIgG-treated PMN had a granular, speckled appearance when stained with FITC-protein A unlike the diffuse and uniform staining of the AM surface shown in Fig. 5. Also, when PMN with attached agg-IgG were incubated at $37^{\circ} \mathrm{C}$ they cleared all their surface IgG within $2 \mathrm{~h}$, in contrast to AM that retained their surface IgG over this period of incubation (Table IV). Furthermore, agg-IgG-treated PMN remained unable to phagocytize nonopsonized S. aureus Cowan I (Table IV). PMN incubated with concentrated lung lavage fluid (containing $\sim 1 \mathrm{mg} \mathrm{IgG} / \mathrm{ml}$ ) did not become positive for surface immunoglobulins by immunofluorescence and, as with agg-IgG treatment, remained unable to phagocytize nonopsonized S. aureus Cowan I (Table IV).

Taken together, these results indicate that normal human lung lavage fluids do not contain appreciable quantities of aggregated or immune-complexed IgG, and that the surface IgG on AM is also not aggregated or immune-complexed.

Phagocytosis by human peritoneal macrophages and by AM from different animal species. In four separate experiments, human peritoneal macrophages phagocytized $59 \pm 4.9 \%$ (mean $\pm S E$ ) of nonopsonized $S$. aureus Cowan I after 60-min incubation. In contrast, only $13 \pm 0.7 \%$ of the protein A-deficient EMS strain was taken up. Also, peritoneal macrophages stained positively with FITC-protein A as was found with AM. Thus, human peritoneal macrophages also appear to possess cytophilic IgG, which can mediate phagocytosis of protein A containing S. aureus.

TABLE II

Inhibition of S. aureus Cowan I Phagocytosis by Protease and Neuraminidase Treatment of AM

\begin{tabular}{cccc}
\hline & \multicolumn{2}{c}{ Inhibition of phagocytosist of } \\
\cline { 2 - 3 } AM treatment & Opsonized bacteria & $\begin{array}{c}\text { Nonopsonized } \\
\text { bacteria }\end{array}$ & $\begin{array}{c}\text { Number } \\
\text { of tests }\end{array}$ \\
\hline Trypsin, $0.1 \mathrm{mg} / \mathrm{ml}$ & $\%$ & $\%$ & \\
$1.0 \mathrm{mg} / \mathrm{ml}$ & $46.3 \pm 4.1$ & $8.0 \pm 2.6$ & 3 \\
Pronase, $1.0 \mathrm{mg} / \mathrm{ml}$ & $57.5 \pm 5.3$ & $17.5 \pm 1.8$ & 2 \\
Neuraminidase, $0.1 \mathrm{U} / \mathrm{ml}$ & $86.7 \pm 1.3$ & $7.7 \pm 3.0$ & 3 \\
\hline
\end{tabular}

- AM were incubated $\left(30 \mathrm{~min}\right.$ at $\left.37^{\circ} \mathrm{C}\right)$ with indicated enzymes, washed, and mixed with either opsonized ( $10 \%$ serum) or nonopsonized staphylococci.

$\downarrow$ The initial rate of phagocytosis was determined (percent uptake at $5 \mathrm{~min}$ ) and these data were used to calculate mean $\pm \mathrm{SE}$ percent inhibition compared with simultaneously run HBSS-treated AM. 
TABLE III

Inhibition of S. aureus Cowan I Phagocytosis by Protein A and Anti-Fc Treatment of AM

\begin{tabular}{cccc}
\hline & \multicolumn{2}{c}{ Inhibition of phagocytösist of } & \\
\cline { 2 - 3 } AM treatment & Opsonized bacteria & Nonopsonized bacteria & $\begin{array}{c}\text { Number } \\
\text { of tests }\end{array}$ \\
\hline & $\%$ & $\%$ & \\
Protein A, $1 \mathrm{mg} / \mathrm{ml}$ & $9.0 \pm 2.6$ & $52.7 \pm 1.0$ & 3 \\
Anti-Fc, $1 \mathrm{mg} / \mathrm{ml}$ & $16.0 \pm 6.5$ & $57.5 \pm 2.3$ & 4 \\
\hline
\end{tabular}

- AM were incubated with protein $A$ or goat $F\left(a b^{\prime}\right)_{2}$ against human IgG Fc (anti-Fc) for $30 \mathrm{~min}$ at $37^{\circ} \mathrm{C}$, washed, and mixed with either opsonized or nonopsonized staphylococci.

I The initial rate of phagocytosis was determined (percent uptake at $5 \mathrm{~min}$ ) and these data were used to calculate the mean $\pm \mathrm{SE}$ percent inhibition of phagocytosis compared with simultaneously run HBSS-treated AM.

Because phagocytosis of staphylococci by AM has been studied in vitro and in vivo in other animal species, phagocytosis by AM from humans, rabbits, rats, and hamsters was compared. In six separate experiments, the mean (range) percent uptake of nonopsonized S. aureus Cowan I was $80(65-88) \%$ for human $\mathrm{AM}, 18(10-30) \%$ for rabbit AM, $11(7-14) \%$ for rat $\mathrm{AM}$, and 26 (17-34)\% for hamster AM. In comparison with Cowan I, the uptake of the protein A-negative mutant strain EMS was strikingly lower for human AM (11 [5-14]\%), but was also significantly lower for AM of the other animal species.

\section{DISCUSSION}

The main goal of this investigation was to elucidate the mechanism of phagocytosis of nonopsonized staphylococci by human AM. We found that phagocytosis of nonopsonized staphylococci by these phagocytes only occurs with protein A-positive strains, and that the efficiency of uptake depends on the amount of protein $A$ on the bacterial surface.

A likely explanation for the protein $A$ receptor mechanism of human AM was found by demonstrating the presence of surface IgG antibodies on these cells.

TABLE IV

Differences between AM Surface IgG and agg-IgG Bound to PMN

\begin{tabular}{|c|c|c|c|c|c|}
\hline \multirow[b]{2}{*}{ Phagocyte } & \multirow[b]{2}{*}{ Pretreatment ${ }^{\circ}$} & \multicolumn{3}{|c|}{$\begin{array}{l}\text { Reactivity with FITC-protein } \mathrm{A} \text { after } 37^{\circ} \mathrm{C} \\
\text { incubation fort }\end{array}$} & \multirow{2}{*}{$\begin{array}{c}\text { Phagocytosis o } \\
\text { nonopsonized } S \\
\text { aureus } \$\end{array}$} \\
\hline & & $1 \min$ & $60 \mathrm{~min}$ & $120 \mathrm{~min}$ & \\
\hline & & & & & $\%$ \\
\hline $\mathrm{AM}$ & GHBSS & $\begin{array}{c}+ \\
\text { (diffuse) }\end{array}$ & + & + & $75 \pm 0.7$ \\
\hline \multirow[t]{3}{*}{ PMN } & GHBSS & - & ND & ND & $11 \pm 3.1$ \\
\hline & Lung fluid & - & ND & ND & $13 \pm 2.6$ \\
\hline & agg-IgG & $\stackrel{+}{+}$ & \pm & - & $15 \pm 0.7$ \\
\hline
\end{tabular}

- $\mathrm{AM}$ and PMN $\left(5 \times 10^{6} / \mathrm{ml} \mathrm{GHBSS}\right)$ were incubated $\left(150 \mathrm{~min}\right.$ at $\left.4^{\circ} \mathrm{C}\right)$ with medium alone (GHBSS), concentrated lung lavage fluid diluted 1:2 in GHBSS, or $1 \mathrm{mg}$ agg-IgG/ $\mathrm{ml}$ GHBSS, then washed twice and used.

$\ddagger$ Washed, pretreated cells were incubated in GHBSS at $37^{\circ} \mathrm{C}$ for indicated times and then stained for surface IgG with FITC-protein A as described in Methods. Positive, + ; trace, \pm ; absent, - . ND, not determined.

$\$$ Washed, pretreated cells were incubated with nonopsonized $S$. aureus Cowan I for $60 \mathrm{~min}$ and the present uptake was determined. Results are mean $\pm \mathrm{SE}$ of three separate experiments. 
Although macrophage surface antibodies have been found in a number of animal species (23-26), little attention has been focused on the presence and role of surface antibodies on human phagocytic cells. Small quantities of IgG, not detectable with fluorescent antibody techniques, have been demonstrated on human PMN and MN by autoradiography (27). In addition, human breast-milk macrophages obtained in the early postpartum period have been shown to contain appreciable quantities of IgA and IgM, but no detectable IgG (28). We now report that human AM have surface IgG antibodies in quantities that permit ready detection by immunofluorescence microscopy. The well known binding of protein $A$ to certain subclasses of human $\operatorname{IgG}(21,29)$ would infer that the observed phagocytosis of nonopsonized staphylococci is the consequence of the interaction between bacterial cell wall protein A and surface IgG molecules of AM.

The AM surface IgG and uptake of nonopsonized staphylococci were resistant to short $(30 \mathrm{~min})$ treatments with several proteolytic enzymes. Although serum IgG is more sensitive to these enzymes than secretory IgA, even serum IgG would not be expected to become extensively degraded by these relatively mild proteolytic conditions $(30,31)$. Longer incubation times ( $\geq 2 \mathrm{~h}$ ) of AM with the same proteases, however, did remove most of the AM surface IgG. In contrast, the AM receptor for opsonized staphylococci was degraded by a 30 -min exposure to proteases. This suggests that $\mathrm{C} 3$ receptors of $\mathrm{AM}$ are involved in the recognition of opsonized but not of nonopsonized staphylococci, since receptors for $\mathrm{C} 3$ are known to be trypsin sensitive (32-35).

In this study we did not determine the subclass(es) of IgG that are present on human AM, and no data is available on the subclass specificities of the IgG receptor of AM. PMN, and MN, however, have been found to bind monomeric and immune-complexed IgG $_{1}$ and $\operatorname{IgG}_{3}$ antibodies (36-38); less binding has been observed with $\operatorname{IgG}_{4}$ or $\operatorname{IgA}$, and $\operatorname{IgG}_{2}, \operatorname{IgM}, \operatorname{IgD}$, and IgE are not cytophilic for PMN and MN (37). Since protein $A$ has its greatest affinity for $\operatorname{IgG}_{1}$ and $\operatorname{IgG}_{2}$, and does not bind to $\operatorname{IgG}_{3}$, one could speculate that human AM surface antibody is primarily of the $\operatorname{IgG}_{1}$ subclass.

The binding of protein A to surface-bound IgG raises the question of the molecular orientation of the IgG molecules on the AM surface. Binding of cytophilic antibodies to macrophages, PMN, and $\mathrm{MN}$ have been demonstrated to involve the Fc region of the antibody molecule $(25,37,39)$. Protein $A$ has also been shown to bind to the Fc portion of IgG $(21,29)$. However, different domains of the $F_{c}$ fragment may be involved. The interaction with $\mathrm{Fc}$ receptors of $\mathrm{PMN}$ or $\mathrm{MN}$ probably involves the $\mathrm{Fc}_{\mathrm{H}} 3$ domain of the IgG molecule
(40-42). Protein A, on the other hand, has been found to bind at a locus between the $\mathrm{C}_{\mathrm{H}} 2$ and $\mathrm{C}_{\mathrm{H}} 3$ domains and does not interfere with the capacity of the $\mathrm{Fc}$ fragment to bind to $\mathrm{Fc}$ receptors $\left(\mathrm{C}_{\mathrm{H}} 3\right.$ domain) or to the first component of complement $\left(\mathrm{C}_{\mathrm{H}} 2\right.$ domain) (4345). Interestingly, injury to human platelets by $S$. aureus has recently been shown also to involve interactions of cell wall protein $\mathrm{A}, \mathrm{IgG}$, and platelet $\mathrm{Fc}$ receptors (46).

The observed increases in AM hexose monophosphate shunt activity and superoxide anion production induced by nonopsonized $S$. aureus do not differ significantly from previously reported AM responses to opsonized staphylococci $(16,17)$. Although it is not known how these responses are triggered, the binding of protein A to IgG has been shown to result in significant conformational changes in the Fc fragment, which may provide the initial stimulus for the metabolic burst (47).

Our experiments indicated that the AM surface IgG are not in an aggregated or immune-complexed state. The uniform and diffuse staining of the AM surface, the persistence of the AM surface IgG upon prolonged incubation at $37^{\circ} \mathrm{C}$, and the ability of the surface IgG to mediate ingestion of bacteria contrast with our results and those of other investigators (48-51) that have studied the interactions between aggregated or immune-complexed antibodies with phagocytic cells. The IgG found on normal human AM more likely fits the category of so called cytophilic immunoglobulins $(52,39)$.

The role in host defense of cytophilic antibodies on human AM, and on its precursor cell, the circulating MN (53), is currently completely unknown. Smoker AM were found to contain large amounts of autofluorescent cytoplasmic inclusions as has been noted by others (22), and one possibility might be that these inclusions represent antigenic material that has been cleared via specific cytophilic antibody. Previous studies suggested that protein A inhibits opsonization for phagocytosis by PMN $(54,55)$. Paradoxically, protein A was found in this study to promote phagocytosis of nonopsonized staphylococci by human $\mathrm{AM}$, and this may be important in local immunity of the human lung. Also, some strains of group $\mathrm{A}$ and the majority of strains of group $\mathrm{C}$ and $\mathrm{G}$ streptococci carry an Fc binding structure analogous to protein A (56). These strains may thus also be phagocytized via cytophilic IgG.

Our findings with human peritoneal macrophages, although obtained from patients, suggest that cytophilic IgG-mediated phagocytosis may be a characteristic that is common to human tissue macrophages. The inefficiency of AM from rabbits, rats, and hamsters to phagocytize nonopsonized staphylococci is in 
agreement with previous work using these animal species (57-60). These species' differences point out that functions of human macrophages cannot be directly inferred from studies using macrophages from other animals.

\section{ACKNOWLEDGMENTS}

We wish to thank Dr. Youngki Kim and Dr. F. G. Cosio for their advice and suggestions, and Dr. William Korchik for his help in obtaining peritoneal dialysate fluids.

This investigation was supported, in part, by U. S. Public Health Service research grants AI-08821-10 and AI-0693115 from the National Institute of Allergy and Infectious Diseases and by funds from the Minnesota Thoracic Society. Dr. Verbrugh is a Postdoctoral International Research Fellow supported by the John E. Fogarty International Center grant FOS-TW02952-01.

\section{REFERENCES}

1. Verhoef, J., P. K. Peterson, Y. Kim, L. D. Sabath, and P. G. Quie. 1977. Opsonic requirements for staphylococcal phagocytosis: heterogeneity among strains. Immunology. 33: 191-197.

2. Peterson, P. K., J. Verhoef, D. Schmeling, and P. G. Quie. 1977. Kinetics of phagocytosis and bacterial killing by human polymorphonuclear leukocytes and monocytes. J. Infect. Dis. 136: 502-508.

3. Quie, P. G., R. P. Messner, and R. C. Williams, Jr. 1968. Phagocytosis in subacute bacterial endocarditis: localization of the primary opsonic site to Fc fragment. J. Exp. Med. 128: 553-570.

4. Wright, A. E., and S. R. Douglas. 1904. An experimental investigation of the role of the body fluids in connection with phagocytosis. Proc. Roy. Soc. (Lond.). 72: 357-370.

5. Li, I. W., and S. Mudd. 1965. The heat-labile serum factor associated with intracellular killing of Staphylococcus aureus. J. Immunol. 94: 852-857.

6. Humphreys, D. W., L. J. Wheat, and A. White. 1974. Staphylococcal heat-stable opsonins. J. Lab. Clin. Med. 84: 122-128.

7. Peterson, P. K., B. J. Wilkinson, Y. Kim, D. Schmeling, S. D. Douglas, P. G. Quie, and J. Verhoef. 1978. The key role of peptidoglycan in the opsonization of Staphylococcus aureus. J. Clin. Invest. 61: 597-609.

8. Verbrugh, H. A., W. C. Van Dijk, M. E. Van Erne, R. Peters, P. K. Peterson, and J. Verhoef. 1980. Opsonic recognition of staphylococci mediated by cell wall peptidoglycan: antibody-independent activation of human complement and opsonic activity of peptidoglycan antibodies. J. Immunol. 124: 1167-1173.

9. Hoidal, J. R., D. Schmeling, and P. K. Peterson. 1981. Phagocytosis, bacterial killing, and metabolism by purified human polymorphonuclear leukocytes, monocytes, and pulmonary alveolar macrophages. J. Infect. Dis. 144: 61-71.

10. Hof, D. G., J. E. Repine, P. K. Peterson, and J. R. Hoidal. 1980. Phagocytosis by human alveolar macrophages and neutrophils: qualitative differences in the opsonic requirements for uptake of Staphylococcus aureus and Streptococcus pneumoniae in vitro. Am. Rev. Respir. Dis. 121: 65-71.

11. Peterson, P. K., Y. Kim, B. J. Wilkinson, D. Schmeling, A. F. Michael, and P. G. Quie. 1978. Dichotomy between opsonization and serum complement activation by encapsulated staphylococci. Infect. Immun. 20: 770-775.

12. McLean, R. H., A. Forsgren, B. Björkstén, Y. Kim, P. G. Quie, and A. F. Michael. Decreased serum factor B concentration associated with decreased opsonization of Escherichia coli in the idiopathic nephrotic syndrome. Pediatr. Res. 11: 910-916.

13. Böyum, A. 1967. Isolation of mononuclear cells and granulocytes from human blood. Isolation of mononuclear cells by one centrifugation and of granulocytes by combining centrifugation and sedimentation of $1 \mathrm{~g}$. Scand. J. Clin. Lab. Invest. 21(Suppl 97): 77-89.

14. Ackerman, S. K., and S. D. Douglas. 1978. Purification of human monocytes on microexudate coated surfaces. J. Immunol. 120: 1372-1374.

15. Hoidal, J. R., J. G. White, and J. E. Repine. 1979. Influence of cationic local anesthetics on the metabolism and ultrastructure of human alveolar macrophages. $J$. Lab. Clin. Med. 93: 857-863.

16. Hoidal, J. R., G. D. Beall, F. L. Rasp, Jr., B. Holmes, J. G. White, and J. E. Repine. 1978. Comparison of the metabolism of alveolar macrophages from humans, rats, and rabbits. J. Lab. Clin. Med. 92: 787-794.

17. Hoidal, J. R., J. E. Repine, G. D. Beall, F. L. Rasp, Jr., and J. G. White. 1978. The effect of phorbol myristate acetate on the metabolism and ultrastructure of human alveolar macrophages. Am. J. Pathol. 91: 469-483.

18. Winblad, S., and C. Ericson. 1973. Sensitized sheep red cells as a reactant for Staphylococcus aureus protein A. Acta Pathol. Microbiol. Scand. Sect. B Microbiol. 81: 150-156.

19. Gajl-Peczalska, K. J., J. A. Hansen, C. D. Bloomfield, and R. A. Good. 1973. B Lymphocytes in untreated patients with malignant lymphoma and Hodgkin's disease. J. Clin. Invest. 52: 3064-3073.

20. Brown, B. W., Jr., and M. Hollander. 1977. Statistics. A Biomedical Introduction. Wiley-Interscience, Div. of John Wiley \& Sons, New York. 261-307.

21. Forsgren, A., and J. Sjöquist. 1966. Protein A from $S$. aureus. I. Pseudoimmune reaction with human gammaglobulin. J. Immunol. 97: 822-827.

22. Martin, R. R. 1973. Altered morphology and increased acid hydrolase content of pulmonary macrophages from cigarette smokers. Am. Rev. Respir. Dis. 107: 596-601.

23. Boyden, S. V. 1964. Cytophilic antibody in guinea pigs with delayed-type hypersensitivity. Immunology. 7:474483.

24. Tizard, I. R. 1969. Macrophage cytophilic antibody in mice. Differentiation between antigen adherence due to these antibodies and opsonic adherence. Int. Arch. Allergy Appl. Immunol. 36: 332-346.

25. Tizard, I. R. 1971. Macrophage-cytophilic antibodies and the functions of macrophage-bound immunoglobulins. Bacteriol. Rev. 35: 365-378.

26. Green, R. J., and J. P. Kreier. 1978. Demonstration of the role of cytophilic antibody in resistance to malaria parasites (Plasmodium berghei) in rats. Infect. Immun. 19: 138-145.

27. Ishizaka, K., H. Tomioka, and T. Ishizaka. 1970. Mechanisms of passive sensitization. I. Presence of IgE and IgG molecules on human leukocytes. J. Immunol. 105: 1459-1467.

28. Pittard, W. B., III, S. H. Polmar, and A. A. Fanaroff. 1977. The breast milk macrophage: a potential vehicle for immunoglobulin transport. J. Reticuloendothel. Soc. 22: 597-603.

29. Kronvall, G., and R. C. Williams, Jr. 1969. Differences 
in anti-protein A activity among IgG sub-groups. J. Immunol. 103: 828-833.

30. Brown, W. R., R. W. Newcomb, and K. Ishizaka. 1970. Proteolytic degradation of exocrine and serum immunoglobulins. J. Clin. Invest. 49: 1374-1380.

31. Underdown, B. J., and K. J. Dorrington. 1974. Studies on the structural and conformational basis for the relative resistance of serum and secretory immunoglobulin A to proteolysis. J. Immunol. 112: 949-959.

32. Lay, W. H., and V. Nussenzweig. 1968. Receptors for complement on leukocytes. J. Exp. Med. 128: 991-1007.

33. Griffin, F. M., C. Bianco, and S. C. Silverstein. 1975. Characterization of the macrophage receptor for complement and demonstration of its functional independence from the receptor for the Fc portion of immunoglobulin G. J. Exp. Med. 141: 1269-1277.

34. Verhoef, J., P. K. Peterson, and P. G. Quie. 1977. Human polymorphonuclear receptors for staphylococcal opsonins. Immunology. 33: 231-239.

35. Shurin, S. S., and T. P. Stossel. 1978. Complement (C3)mediated phagocytosis by lung macrophages. J. Immunol. 120: 1305-1312.

36. Huber, H., S. D. Douglas, J. Nusbacher, S. Kochwa, and R. E. Rosenfield. 1971. IgG subclass specificity of human monocyte receptor sites. Nature (Lond.). 229: 419-420.

37. Lawrence, D. A., W. O. Weigle, and H. L. Speigelberg. 1975. Immunoglobulins cytophilic for human lymphocytes, monocytes, and neutrophils. J. Clin. Invest. 55: 368-376.

38. Alexander, M. D., J. A. Andrews, R. G. Q. Leslie, and N. J. Wood. 1978. The binding of human and guinea pig IgG subclasses to homologous macrophage and monocyte Fc receptors. Immunology. 35: 119-144.

39. Berken, A., and B. Benacerraf. 1966. Properties of antibodies cytophilic for macrophages. J. Exp. Med. 123: 119-144.

40. Ciccimarra, F., F. S. Rosen, and E. Merler. 1975. Localization of the IgG effector site for monocyte receptors. Proc. Natl. Acad. Sci. U. S. A. 72: 2081-2086.

41. Yasmeen, D., J. R. Ellison, K. J. Dorrington, and R. H. Painter. 1973. Evidence for the domain hypothesis: location of the site of cytophilic activity toward guinea pig macrophages in the $\mathrm{C}_{\mathrm{H}} 3$ homology region of human immunoglobulin G. J. Immunol. 110: 1706-1709.

42. Okator, G. P., M. W. Turner, and F. C. Hay. 1974. Localization of monocyte binding site of human immunoglobulin G. Nature (Lond.). 248: 228-230.

43. Lancet, D., D. Isenman, J. Sjödahl, J. Sjöquist, and I. Pecht. 1978. Interactions between staphylococcal protein $\mathrm{A}$ and immunoglobulin domains. Biochem. Biophys. Res. Commun. 85: 608-614.

44. Deisenhofer, J., T. A. Jones, R. Huber, J. Sjödahl, and J. Sjöquist. 1978. Crystallization, crystal structure analysis, and atomic model of the complex formed by a human Fc fragment and fragment B of protein A from Staphylococcus aureus. Hoppe-Seyler's Z. Physiol. Chem. 359: 975-985.

45. Sulica, A., C. Medeşan, M. Laky, D. Onică, J. Sjöquist, and V. Ghetie. 1979. Effect of protein A of Staphylococcus aureus on the binding of monomeric and poly- meric IgG to Fc receptor-bearing cells. Immunology. 38: 173-179.

46. Hawiger, J., S. Steckley, D. Hammond, C. Cheng, S. Timmons, A. D. Glick, and R. M. Des Pres. 1979. Staphylococci-induced human platelet injury mediated by protein $\mathrm{A}$ and immunoglobulin $\mathrm{G}$ Fc fragment receptor. J. Clin. Invest. 64: 931-937.

47. Langone, J. J., M. D. P. Boyle, and T. Borsos. 1978. Studies on the interaction between protein $A$ and immunoglobulin G. I. Effect of protein A on the functional activity of IgG. J. Immunol. 121: 327-331.

48. Starkebaum, G., and W. P. Arend. 1979. Neutrophilbinding immunoglobulin $G$ in systemic lupus erythematosus. J. Clin. Invest. 64: 902-912.

49. Knutson, D. W., A. Kÿlstra, and L. E. Van Es. 1977. Association and dissociation of aggregated IgG from rat peritoneal macrophages. J. Exp. Med. 145: 1368-1381.

50. Leslie, R. G. Q. 1980. Macrophage handling of soluble immunocomplexes. Ingestion and digestion of surfacebound complexes at 4,20 , and $37^{\circ} \mathrm{C}$. Eur. J. Immunol. 10: $323-333$.

51. Alexander, E. L., J. A. Titus, and D. M. Segal. 1979. Human leukocyte Fc (IgG) receptors: quantitation and affinity with radiolabeled affinity cross-linked rabbit IgG. J. Immunol. 123: 295-302.

52. Boyden, S. V., and E. Sorkin. 1960. The adsorption of antigen by spleen cells previously treated with antiserum in vitro. Immunology. 3: 272-283.

53. Hocking, W. G., and D. W. Golde. 1979. The pulmonary-alveolar macrophage (first of two parts). N. Engl. J. Med. 301: 586-587.

54. Forsgren, A., and P. G. Quie. 1974. Effects of staphylococcal protein A on heat-labile opsonins. J. Immunol. 112: $1177-1180$.

55. Peterson, P. K., J. Verhoef, L. D. Sabath, and P. G. Quie. 1977. Effect of protein A on staphylococcal opsonization Infect. Immun. 17: 475-482.

56. Myhre, E. B., and G. Kronvall. 1977. Heterogeneity of nonimmune immunoglobulin Fc reactivity among grampositive cocci: description of three major types of receptors for human immunoglobulin G. Infect. Immun. 17: 475-482.

57. LaForce, F. M. 1976. Effect of alveolar lining material on phagocytic and bactericidal activity of lung macrophages against S. aureus. J. Lab. Clin. Med. 88: 691699 .

58. Juers, J. A., R. M. Rogers, J. B. McCurdy, and W. W. Cook. 1976. Enhancement of bactericidal capacity of alveolar macrophages by human alveolar lining material. J. Clin. Invest. 58: 271-275.

59. LaForce, F. M., W. J. Kelly, and G. L. Huber. 1973. Inactivation of staphylococci by alveolar macrophages with preliminary observations on the importance of alveolar lining material. Am. Rev. Respir. Dis. 108: 784790.

60. Murphy, S. A., R. K. Root, and A. D. Schreiber. 1979. The role of antibody and complement in phagocytosis by rabbit alveolar macrophages. J. Infect. Dis. 140: 896903. 